\title{
Hubungan Asupan Natrium, Gaya Hidup, dan Faktor Genetik dengan Tekanan Darah pada Penderita Penyakit Jantung Koroner
}

\author{
Bertalina $^{1}$, Suryani $\mathrm{AN}^{2}$ \\ ${ }^{1,2}$ Jurusan Gizi, Politeknik Kesehatan Tanjungkarang \\ Email: ubertalina@yahoo.com
}

\begin{abstract}
Effects of Sodium Intake, Lifestyle, and Genetic Factors on CHD Patient's Blood Pressure Coronary Heart Disease. One of degenerative disease that caused by heart function declining and blood vessels. The major risk factors for coronary heart disease is blood pressure. Blood pressure can be affected by various factors such as age, gender, hypertension genetic factors, dietary intake, and lifestyle. This research determines the effects of sodium intake, lifestyle and genetic factors on coronary heart disease (CHD) patient's blood pressure. This research was analytic research with cross sectional approach. Independent variables in this research are sodium intake, physical activity, smoking habits, and hypertension genetic factors with dependent variable is blood pressure in CHD patients. 96 CHD patients were admitted in the research. Respondents characteristics were mostly men (56.3\%), 46-55 years old (36.5\%) and 56-65 years old (36.5\%), most education backgrounds were high school (41.7\%), and without any occupation (32.3\%). Most respondents had high blood pressure $(51 \%)$, inadequate sodium intake $(52.1 \%)$, have moderate physical activity (92.7\%), do not smoke (91.7\%), and have hypertension genetic factor $(57.3 \%)$. Based on bivariate results showed that there was a significant correlation between sodium intake $(\mathrm{p}$-value $=0.004)$ and hypertension genetic factors $(\mathrm{p}$-value $=0.001)$ with $\mathrm{CHD}$ patient's blood pressure but there was no significant correlation between physical activity ( $p$-value=1.000) and smoking habits ( $\mathrm{p}$-value $=1.000$ ). It is concluded that controlling food intake and maintain normal blood pressure could minimize heart failure and death risk in CHD patients.
\end{abstract}

Keywords: Blood pressure, Sodium intake, Lifestyle, Genetic factors

\begin{abstract}
Abstrak: Hubungan Asupan Natrium, Gaya Hidup, dan Faktor Genetik dengan Tekanan Darah pada Penderita Penyakit Jantung Koroner. Penyakit jantung koroner merupakan salah satu penyakit degeneratif yang disebabkan karena menurunnya fungsi jantung dan pembuluh darah. Faktor resiko utama penyakit jantung koroner ialah tekanan darah. Tekanan darah dapat dipengaruhi oleh berbagai faktor, usia, perbedaan jenis kelamin, adanya atau tidaknya faktor genetik hipertensi, asupan makanan, serta pengaturan gaya hidup. Tujuan penelitian ini adalah diketahuinya hubungan asupan natrium, gaya hidup, dan faktor genetik dengan tekanan darah pada penderita jantung koroner. Jenis penelitian analitik dengan pendekatan cross sectional. Variabel dalam penelitian ini terdiri dari variabel independen yaitu asupan natrium, kategori aktivitas fisik, kebiasaan merokok, dan faktor genetik hipertensi serta variabel dependen yaitu tekanan darah pasien penderita penyakit jantung koroner. Populasi adalah pasien jantung koroner yang berkunjung di RSAM Provinsi Lampung. Sampel pada penelitian ini berjumlah 96 responden. Hasil menunjukkan bahwa distribusi jenis kelamin paling banyak laki-laki (56,3\%), kelompok umur paling banyak 46-55 tahun (36,5\%) dan kelompok umur 56-65 tahun (36,5\%), tingkat pendidikan terakhir paling banyak SMA/SLTA $(41,7 \%)$, jenis pekerjaan paling banyak yaitu tidak bekerja $(32,3 \%)$, tekanan darah responden paling banyak tekanan darah tinggi $(51 \%)$, asupan natrium responden tergolong tidak baik $(52,1 \%)$, kategori aktivitas fisik responden tergolong ringan $(92,7 \%)$, responden tidak memiliki kebiasaan merokok $(91,7 \%)$, dan responden yang memiliki faktor genetik hipertensi $(57,3 \%)$. Berdasarkan hasil uji statistik didapat ada hubungan yang signifikan antara asupan natrium ( $p$-value $=0,004)$ dan faktor genetik hipertensi $(p$ value $=0,001)$ dengan tekanan darah serta tidak ada hubungan yang signifikan antara kategori aktivitas fisik ( $p$-value $=1,000)$ dan kebiasaan merokok $(p$-value $=1,000)$ dengan tekanan darah. Pengendalian tekanan darah berguna untuk memperkecil resiko terserang penyakit gagal jantung maupun kematian melalui pengaturan asupan makanan serta mampu mengontrol tekanan darah agar tetap dalam batas normal.
\end{abstract}

Kata kunci: Tekanan darah, Asupan natrium, Gaya hidup, Faktor genetik

Perubahan yang terjadi dalam kehidupan sekarang ini tak lepas dari adanya pengaruh era globalisasi. Era globalisasi mengubah banyak hal baik dari segi ilmu pengetahuan dan teknologi 
masa kini. Perubahan tersebut dapat secara tidak langsung mempengaruhi perubahan gaya hidup dan pola makan manusia. Perubahan gaya hidup mengakibatkan aktivitas manusia menjadi lebih santai dan kurang bergerak serta perubahan pola makan makanan yang instan atau cepat saji. Perubahan gaya hidup ini dapat dengan mudah memicu timbulnya berbagai penyakit degeneratif (Manganti, 2012).

Penyakit degeneratif yang berarti penurunan progresif dari efisiensi suatu organ atau perubahan yang makin menjadi buruk dengan kehilangan fungsi dan perubahanperubahan kimia dalam jaringan (Rahayu, 2014). Penyakit degeneratif yang muncul akibat pola makan makanan siap saji atau instan serta gaya hidup yang kurang aktivitas menjadi salah satu pemicu utama munculnya penyakit degeneratif yang meliputi penyakit diabetes melitus (DM), osteoporosis, kanker, maupun penyakit kardiovaskuler (Khasanah, 2012).

Penyakit kardiovaskuler merupakan salah satu penyakit degeneratif yang disebabkan karena menurunnya fungsi jantung dan pembuluh darah, seperti penyakit jantung koroner, penyakit gagal jantung, hipertensi, dan stroke.Penyakit jantung koroner merupakan keadaan yang sering ditemukan pada kelompok masyarakat yang sudah makmur atau negara berkembang. Namun, pada sebagian besar negara industri, penyakit jantung koroner (PJK) merupakan satu-satunya penyebab kematian yang paling sering dijumpai dan sering menjadi penyebab sekitar sepertiga dari semua kematian (Mann dan Alexandra, 2014).

Menurut data World Heart Federation (2012) jumlah penduduk dunia yang meninggal akibat penyakit kardiovaskuler sebanyak 17,3 juta di tahun 2008. Penyakit kardiovaskuler ini paling banyak diderita oleh penduduk di bagian Indo-Pasifik yaitu sebanyak 4.735.000 jiwa, diikuti wilayah benua Eropa sebanyak 4.584.000 jiwa, Asia Tenggara sebanyak 3.616.000 jiwa, benua Amerika sebanyak 1.944.000 jiwa, benua Afrika sebanyak 1.254.000 jiwa, dan wilayah Mediterania Timur sebanyak 1.195.000 jiwa. Wilayah Asia Tenggara sendiri Indonesia menempati urutan ke-4 setelah Negara Laos, Kamboja, dan Filiphina yang memiliki prevalensi penyakit jantung koroner (WHO, 2013).

Prevalensi penyakit jantung koroner di Indonesia masih cukup tinggi. Berdasarkan data Riset Kesehatan Dasar (2013), prevalensi penyakit jantung koroner di Indonesia tahun 2013 menurut diagnosis dokter sebesar $0,5 \%$ atau diperkirakan sekitar 883.447 orang, sedangkan berdasarkan diagnosis dokter dan gejala yang sudah ada sebesar $1,5 \%$ atau diperkirakan sekitar 2.650.340 orang. Dilihat dari diagnosis dokter, provinsi di Indonesia dengan prevalensi penyakit jantung koroner paling tinggi yaitu provinsi Jawa Barat sebanyak 160.812 jiwa $(0,5 \%)$ dan prevalensi jantung koroner berdasarkan diagnosis dan adanya gejala paling banyak di provinsi Jawa Timur sebanyak 375.127 jiwa (1,3\%). Provinsi Lampung untuk prevalensi penyakit jantung koroner menurut diagnosis dokter sebesar 0,2\% atau sebanyak 11.121 jiwa. Sedangkan prevalensi penyakit jantung koroner menurut diagnosis dokter dan adanya gejala sebesar $0,4 \%$ atau sebanyak 22.242 jiwa (Riskesdas, 2013). Menurut hasil Riskesdas (2013) provinsi Lampung, prevalensi penyakit jantung koroner menurut diagnosa dokter atau tenaga kesehatan, kota Bandarlampung masuk dalam 5 kabupaten/ kota dengan nilai prevalensi tertinggi. Sedangkan penyakit jantung koroner di kota Bandar Lampung yang didiagnosa tenaga kesehatan dengan adanya gejala masih di atas rata-rata prevalensi penyakit jantung koroner di provinsi Lampung yaitu di atas $0,4 \%$ yang merupakan prevalensi terbesar ke-3 setelah kabupaten Lampung Barat dan kota Metro.

Penyakit jantung koroner sendiri dapat disebabkan oleh berbagai faktor kehidupan, baik faktor yang tidak dapat diubah maupun faktor yang masih dapat diubah. Faktor yang tidak dapat diubah terhadap kejadian penyakit jantung koroner yaitu: usia, jenis kelamin, dan adanya riwayat keluarga. Sedangkan faktor yang masih dapat diubah ialah hipertensi, pola makan, aktivitas tubuh, dislipidemia, obesitas, maupun kebiasaan merokok (World Heart Federation, 2012). Faktor risiko utama penyakit jantung koroner adalah tekanan darah tinggi/hipertensi yang dapat menyebabkan beban kerja jantung menjadi lebih berat pada penderita penyakit jantung koroner (Anwar, 2004). Adanya gejala tekanan darah tinggi/ hipertensi memperbesar risiko terserang penyakit gagal jantung, serangan jantung, pembesaran ventrikel kiri jantung, penyakit ginjal kronis dan stroke (Noviyanti, 2015). Oleh karena itu, pentingnya pengendalian tekanan darah pada penderita penyakit jantung koroner guna menghindari serangan jantung yang akan berakibat pada kematian.

Dilihat dari berbagai faktor tersebut, faktor genetik atau riwayat keluarga maupun gizi (asupan makanan) turut memberikan konstribusi terhadap etiologi kejadian hipertensi pada penyakit jantung koroner, tetapi modifikasi gaya hidup juga jelas menjadi cara yang paling efektif untuk mengurangi risiko hipertensi pada populasi atau penduduk yang berisiko tinggi mengalami 
penyakit jantung koroner (Mann dan Alexandra, 2014). Penelitian Aliffian (2013) menyebutkan asupan natrium mempunyai pengaruh terhadap tekanan darah. Peningkatan tekanan darah pada penderita penyakit jantung koroner disebabkan karena asupan makanan tinggi natrium. Sedangkan gaya hidup dengan kurangnya aktivitas fisik dan memiliki kebiasaan merokok juga memiliki pengaruh terhadap tekanan darah pada penderita penyakit jantung koroner.

Penelitian Sulviana tahun 2008 menyebutkan ada hubungan yang signifikan antara kebiasaan merokok dengan tekanan darah diastolik responden.Selain itu, bahaya merokok yang terutama adalah kejadian hipertensi, penyakit jantung koroner dan gangguan kesehatan yang lebih luas (Sitorus, 2010). Menurut penelitian Yulsam (2015) menyebutkan bahwa ada riwayat hipertensi pada penderita penyakit jantung koroner.

Menurut data dari RSUD Dr. H. Abdul Moeloek Provinsi Lampung, jumlah kunjungan penderita jantung koroner di Poli Jantung mengalami peningkatan. Pada tahun 2012 sebanyak 916 orang, pada tahun 2013 sebanyak 1.609 orang, pada tahun 2014 sebanyak 4.065 orang, dan pada tahun 2015 sebanyak 11.359 orang.

Berdasarkan uraian di atas, peneliti tertarik untuk meneliti "Hubungan Asupan Natrium, Gaya Hidup, dan Faktor Genetik dengan Tekanan Darah Pada Penderita Jantung Koroner di Poli Jantung".

\section{METODE}

Jenis penelitian analitik dengan rancangan penelitian cross sectional. Dalam penggunaan studi cross sectional pengukuran variabel dependen yaitu tekanan darah dan variabel independen yaitu asupan natrium, gaya hidup, dan faktor genetik yang dilakukan pada waktu yang bersamaan.

Populasi dalam penelitian ini adalah penderita jantung koroner di Poli Jantung RSUD Dr. H. Abdul Moeloek Provinsi Lampung yang melakukan kunjungan setiap 1 kali dalam 1 bulan. Sampel pada penelitian ini ditentukan berdasarkan pertimbangan peneliti dengan menggunakan kriteria inklusi.

\section{HASIL}

\section{A. ANALISIS UNIVARIAT}

Tabel 1. Distribusi Frekuensi berdasarkan Karakteristik/ Gambaran Umum Responden

\begin{tabular}{|c|c|c|}
\hline \multirow{2}{*}{ Variabel } & \multicolumn{2}{|c|}{ Jumlah } \\
\hline & n & $\%$ \\
\hline \multicolumn{3}{|l|}{ Jenis Kelamin } \\
\hline Laki-Laki & 54 & 56,3 \\
\hline Perempuan & 42 & 43,7 \\
\hline \multicolumn{3}{|l|}{ Usia } \\
\hline $17-35$ & 3 & 3 \\
\hline $36-45$ & 11 & 11,5 \\
\hline $46-55$ & 35 & 36,5 \\
\hline $56-65$ & 35 & 36,5 \\
\hline$>66$ & 12 & 11,5 \\
\hline \multicolumn{3}{|l|}{ Pendidikan } \\
\hline SD & 8 & 8,3 \\
\hline SLTP/SMP & 16 & 16,7 \\
\hline SLTA/SMA & 40 & 41,7 \\
\hline Perguruan Tinggi & 32 & 33,3 \\
\hline \multicolumn{3}{|l|}{ Pekerjaan } \\
\hline Tidak Bekerja & 31 & 32,3 \\
\hline Ibu Rumah Tangga & 22 & 22,9 \\
\hline PNS & 6 & 6,3 \\
\hline Peg. Swasta & 9 & 9,4 \\
\hline Guru & 10 & 10,4 \\
\hline Wiraswasta & 4 & 4,1 \\
\hline Lainnya (petani, supir, dst) & 14 & 14,6 \\
\hline \multicolumn{3}{|l|}{ TekananDarah } \\
\hline Tek. darah tinggi & 49 & 51 \\
\hline Tek. darah normal & 47 & 49 \\
\hline \multicolumn{3}{|l|}{ Asupan Natrium } \\
\hline Tidak baik & 50 & 52,1 \\
\hline Baik & 46 & 47,9 \\
\hline \multicolumn{3}{|l|}{ Aktifitas Fisik } \\
\hline Berat & 7 & 7,3 \\
\hline Ringan & 89 & 92,7 \\
\hline \multicolumn{3}{|l|}{ Kebiasaan Merokok } \\
\hline Merokok & 8 & 8,3 \\
\hline Tidak Merokok & 88 & 91,7 \\
\hline \multicolumn{3}{|l|}{ Faktor Genetik } \\
\hline Ada Faktor Genetik & 55 & 57,3 \\
\hline Tidak Ada Faktor Genetik & 41 & 42,7 \\
\hline Jumlah & 96 & 100,0 \\
\hline
\end{tabular}

Berdasarkan tabel 1 dapat diketahui bahwa jenis kelamin laki-laki berjumlah 54 orang $(53,4 \%)$ dan perempuan berjumlah 42 orang (43,7\%); usia responden paling banyak pada kelompok usia 46-55 tahun sebanyak 35 orang $(36,5 \%)$ dan 56-65 tahun sebanyak 35orang (36,5\%); pendidikan terakhir responden yang paling banyak adalah SLTA/ SMA yaitu 40 orang (41,7\%); pekerjaan responden paling banyak yaitu responden yang tidak bekerja berjumlah 31 orang $(32,3 \%)$; tekanan darah responden terdiri 
dari tekanan darah tinggi yang berjumlah 56 orang $(58,3 \%)$ dan responden dengan tekanan darah normal berjumlah 40 orang $(41,7 \%)$; asupan natrium responden yaitu asupan natrium kategori tidak baik sebanyak 50 orang $(52,1 \%)$; kategori aktfitas fisik responden yang memiliki aktifitas fisik ringan yaitu sebanyak 89 orang $(92,7 \%)$; responden yang tidak memiliki kebiasaan merokok sebanyak 88 orang $(91,7 \%)$; responden yang memiliki faktor genetik hipertensi sebanyak 55 orang $(57,3 \%)$ dan responden yang tidak memiliki faktor genetik hipertensi yaitu sebanyak 41 orang $(42,7 \%)$.

\section{B. ANALISIS BIVARIAT}

\section{Hubungan Asupan Natrium dengan Tekanan Darah}

Tabel 2. Hubungan Asupan Natrium dengan Tekanan Darah

\begin{tabular}{|c|c|c|c|c|c|c|c|}
\hline \multirow{3}{*}{$\begin{array}{c}\text { Asupan } \\
\text { Natrium }\end{array}$} & \multicolumn{4}{|c|}{ Tekanan Darah } & \multirow{2}{*}{\multicolumn{2}{|c|}{ Total }} & \multirow{3}{*}{$\begin{array}{c}p- \\
\text { value }\end{array}$} \\
\hline & \multicolumn{2}{|c|}{ Tinggi } & \multicolumn{2}{|c|}{ Normal } & & & \\
\hline & $\mathbf{n}$ & $\%$ & $\mathbf{n}$ & $\%$ & $\mathbf{n}$ & $\%$ & \\
\hline Tidak baik & 33 & 66 & 17 & 34 & 50 & 100 & \\
\hline Baik & 16 & 34,8 & 30 & 65,2 & 46 & 100 & 0,004 \\
\hline Jumlah & 49 & 51 & 47 & 49 & 96 & 100 & \\
\hline
\end{tabular}

Berdasarkan tabel 2 dapat diketahui bahwa responden yang memiliki kategori asupan natrium tidak baik sebanyak $66 \%$ mempunyai tekanan darah tinggi dan responden yang memiliki kategori asupan natrium baik sebanyak $34,8 \%$ mempunyai tekanan darah tinggi. Hasil uji statistik diperoleh nilai $p$-value $=0,004$ (lebih kecil dari nilai alpha $=0,05)$ yang berarti Ho ditolak sehingga dapat disimpulkan bahwa ada hubungan yang signifikan antara asupan natrium dengan tekanan darah.

\section{Hubungan Aktivitas Fisik dengan Tekanan Darah}

Tabel 3. Distribusi Aktifitas Fisik dengan Tekanan Darah

\begin{tabular}{|c|c|c|c|c|c|c|c|}
\hline \multirow{3}{*}{$\begin{array}{l}\text { Kategori } \\
\text { Aktifitas } \\
\text { Fisik }\end{array}$} & \multicolumn{4}{|c|}{ Tekanan Darah } & \multirow{2}{*}{\multicolumn{2}{|c|}{ Tota }} & \multirow{3}{*}{$\begin{array}{c}p- \\
\text { value }\end{array}$} \\
\hline & \multicolumn{2}{|c|}{ Tinggi } & \multicolumn{2}{|c|}{ Normal } & & & \\
\hline & $\mathbf{n}$ & $\%$ & $\mathbf{n}$ & $\%$ & $\mathbf{n}$ & $\%$ & \\
\hline Berat & 4 & 57,1 & 3 & 42,9 & 7 & 100 & \\
\hline Ringar & 45 & 50,6 & 44 & 49,4 & 89 & 100 & 1,00 \\
\hline Jumlah & 49 & 51 & 47 & 49 & 96 & 100 & \\
\hline
\end{tabular}

Berdasarkan tabel 3 dapat diketahui bahwa bahwa responden yang memiliki kategori aktivitas fisik berat sebanyak $57,1 \%$ mempunyai tekanan darah tinggi dan responden yang memiliki kategori aktivitas fisik ringan sebanyak $50,6 \%$ mempunyai tekanan darah tinggi. Hasil uji statistik diperoleh nilai $p$-value $=1,000$ (lebih besar dari nilai alpha $=0,05$ ) yang berarti Ho diterima sehingga dapat disimpulkan bahwa tidak ada hubungan yang signifikan antara kategori aktifitas fisik dengan tekanan darah

\section{Hubungan Hubungan Kebiasaan Merokok dengan Tekanan Darah}

\begin{tabular}{|c|c|c|c|c|c|c|c|}
\hline \multirow{3}{*}{$\begin{array}{c}\text { Kebiasaan } \\
\text { Merokok }\end{array}$} & \multicolumn{4}{|c|}{ Tekanan Darah } & \multirow{2}{*}{\multicolumn{2}{|c|}{ Total }} & \multirow{3}{*}{$\begin{array}{c}p- \\
\text { value }\end{array}$} \\
\hline & \multicolumn{2}{|c|}{ Tinggi } & \multicolumn{2}{|c|}{ Normal } & & & \\
\hline & $\mathbf{n}$ & $\%$ & $\mathbf{n}$ & $\%$ & $\mathrm{n}$ & $\%$ & \\
\hline Merokok & 4 & 50 & 4 & 50 & 8 & 100 & \\
\hline $\begin{array}{l}\text { Tidak } \\
\text { Merokok }\end{array}$ & 45 & 51,1 & 43 & 48,9 & 88 & 100 & 1,000 \\
\hline Jumlah & 49 & 51 & 47 & 49 & 96 & 100 & \\
\hline
\end{tabular}

Berdasarkan tabel 4 dapat diketahui bahwa bahwa responden yang memiliki kebiasaan merokok sebanyak 50\% mempunyai tekanan darah tinggi dan responden yang tidak memiliki kebiasaan merokok sebanyak $51,1 \%$ mempunyai tekanan darah tinggi. Hasil uji statistik diperoleh nilai $p$-value $=1,000$ (lebih besar dari nilai alpha $=0,05$ ) yang berarti Ho diterima sehingga dapat disimpulkan bahwa tidak ada hubungan yang signifikan antara kebiasaan merokok dengan tekanan darah.

\section{Hubungan Faktor Genetik Hipertensi dengan Tekanan Darah}

Tabel 5. Distribusi Faktor Genetik Hipertensi dengan Tekanan Darah

\begin{tabular}{|c|c|c|c|c|c|c|c|}
\hline \multirow{3}{*}{$\begin{array}{c}\text { Faktor } \\
\text { Genetik } \\
\text { Hipertensi }\end{array}$} & \multicolumn{4}{|c|}{ Tekanan Darah } & \multirow{2}{*}{\multicolumn{2}{|c|}{ Total }} & \multirow{3}{*}{$\begin{array}{c}p- \\
\text { value }\end{array}$} \\
\hline & \multicolumn{2}{|c|}{ Tinggi } & \multicolumn{2}{|c|}{ Normal } & & & \\
\hline & $\mathbf{n}$ & $\%$ & $\mathbf{n}$ & $\%$ & $\mathbf{n}$ & $\%$ & \\
\hline Ada & 37 & 67,3 & 18 & 32,7 & 55 & 100 & \\
\hline Tidak & 12 & 29,2 & 29 & 70,7 & 41 & 100 & 0,00 \\
\hline Jumlah & 49 & 51 & 47 & 49 & 96 & 100 & \\
\hline
\end{tabular}

Berdasarkan tabel 5 dapat diketahui bahwa bahwa responden yang memiliki faktor gentik hipertensi sebanyak $67,3 \%$ mempunyai tekanan darah tinggi dan responden yang tidak memiliki faktor genetik hipertensi sebanyak 29,2\% mempunyai tekanan darah tinggi. Hasil uji statistik diperoleh nilai $p$-value $=0,001$ (lebih kecil dari nilai alpha $=0,05$ ) yang berarti Ho ditolak sehingga dapat disimpulkan bahwa ada hubungan yang signifikan antara adanya faktor genetik hipertensi dengan tekanan darah. 


\section{PEMBAHASAN}

\section{A. UNIVARIAT}

\section{Jenis Kelamin}

Jenis kelamin responden dalam penelitian ini berjumlah 96 orang dengan presentase tertinggi ialah laki-laki sebanyak 54 orang $(56,3 \%)$. Salah satu faktor yang tidak dapat diubah dalam mempengaruhi tekanan darah ialah jenis kelamin. Jenis kelamin laki-laki lebih banyak menderita tekanan darah tinggi dibanding perempuan. Hal ini dapat terjadi akibat berbagai faktor yang mempengaruhi tekanan darah pada laki-laki seperti stress, kelelahan, dan jadwal makan yang tidak teratur.Menurut Depkes RI (2006) jenis kelamin laki-laki diduga memiliki gaya hidup yang cenderung dapat meningkatkan tekanan darah dibandingkan dengan wanita. Gaya hidup yang dimaksud ialah seperti memiliki kebiasaan merokok, konsumsi alkohol, hingga faktor sosial ekonomi yang dialami oleh individu tersebut (Depkes RI, 2006).

Selain itu, hasil penelitian Sihombing (2010) menyatakan bahwa presentase angka kejadian hipertensi pada laki-laki lebih tinggi 1,2 kali dibandingkan terhadap perempuan. Sedangkan menurut Meylisa (2015) angka kejadian penyakit kardiovaskuler dan tekanan darah tinggi lebih banyak pada pria dibandingkan perempuan sebelum memasuki masa menopause.

Wanita yang belum mengalami menopause dilindungi oleh hormon estrogen yang berperan dalam meningkatkan kadar High Density Lipoprotein (HDL). Kadar kolesterol HDL yang tinggi merupakan faktor pelindung dalam mencegah terjadinya proses aterosklerosis. Efek perlindungan estrogen dianggap sebagai penjelasan adanya imunitas wanita pada usia premenopause. Pada premenopause wanita mulai kehilangan sedikit demi sedikit hormon estrogen yang selama ini melindungi pembuluh darah dari kerusakan. Proses ini terus berlanjut dimana hormon estrogen tersebut berubah kuantitasnya sesuai dengan umur wanita secara alami (Anggraini, dkk. 2009).

\section{Usia}

Usia responden dalam penelitian ini dikelompokkan berdasarkan kelompok usia Depkes RI tahun 2009. Usia adalah lamanya waktu hidup yaitu terhitung sejak lahir sampai dengan sekarang. Penentuan usia dilakukan dengan menggunakan hitungan tahun.

Usia yang semakin bertambah akan mempengaruhi tekanan darah pasien penyakit jantung koroner. Hasil penelitian ini tidak jauh berbeda dengan penelitian Meylisa, dimana hasilnya menunjukkan semakin bertambahnya usia semakinmeningkatkan risiko mengalami hipertensi yang mulai terlihat pada kelompok usia 40-45 tahun sebanyak $8 \%$ dan kemudian meningkat pada kelompok usia $>55$ tahun yang lebih berisiko sebanyak $68 \%$ untuk mengalami hipertensi dibandingkan dengan kelompok usia $<40$ tahun (Meylisa, 2015).

Hasil penelitian dalam kelompok usia tekanan darah tinggi ini sesuai dengan teori bahwa usia yang semakin bertambah pada seseorang menyebabkan perubahan alamiah dalam tubuh yang mempengaruhi jantung, pembuluh darah dan hormon (Mubin, MF, 2010).

Menurut Depkes RI tahun 2006 tingginya angka kejadian hipertensi sejalan dengan bertambahnya usia, disebabkan oleh perubahan struktur pada pembuluh darah besar, sehingga lumen menjadi lebih sempit dan dinding pembuluh darah menjadi lebih kaku sehingga dapat menyebabkan meningkatnya tekanan darah sistolik.

\section{Pendidikan}

Pendidikan adalah segala daya upaya dan semua usaha untuk membuat masyarakat dapat mengembangkan potensi manusia.Berdasarkan tingkat pendidikan responden menunjukkan presentase tertinggi pada kategori sekolah menengah atas (SMA) yaitu sebanyak 40 orang $(41,7 \%)$. Hal ini sejalan dengan hasil penelitian Roslina tahun 2008 bahwa pendidikan terbanyak pada penderita hipertensi ialah tingkat pendidikan SMA/ SLTA. Penelitian yang dilakukan oleh Aliffian (2013) juga menunjukkan bahwa responden memiliki tingkat pendidikan paling banyak ialah pada tingkat SMA.

Tingkat pendidikan seseorang mempengaruhi kemampuan seseorang dalam menerima informasi dan mengolahnya sebelum menjadi perilaku yang baik atau yang buruk sehingga berdampak pada status kesehatannya (Notoadmodjo, 2010). Menurut Kusumastuti (2014) semakin tinggi pendidikan yang dimiliki seseorang maka dapat menambah pengetahuannya terutama terpaparnya informasi dari pendidikan informal maupun petugas kesehatan mengenai berbagai penyakit.

\section{Pekerjaan}

Pekerjaan adalah aktivitas atau kegiatan yang dilakukan oleh responden sehingga memperoleh penghasilan. Karakteristik responden berdasarkan jenis pekerjaan dengan hasil presentase tertinggi ialah responden yang tidak bekerja sebanyak 31 orang $(32,3 \%)$. Hal ini sesuai dengan penelitian Roslina (2008) dimana responden yang tidak bekerja paling banyak 
(50\%) pada pasien hipertensi. Jenis pekerjaan seseorang juga berpengaruh terhadap hipertensi, dimana individu yang aktivitasnya rendah beresiko terkena hipertensi sekitar $30-50 \%$ dari pada individu yang aktif disebabkan oleh kurangnya aktivitas yang dilakukan dimana kebanyakan mereka hanya berdiam diri di rumah dengan rutinitas yang membuat mereka suntuk (Anggraini, dkk 2009).

Berdasarkan hasil penelitian responden yang tidak bekerja sebelum didiagnosa penyakit jantung koroner sebanyak 9 orang $(29,1 \%)$ dan responden yang didiagnosa penyakit jantung koroner sebelum berhenti bekerja ialah sebanyak 22 orang $(70,9 \%)$. Responden penyakit jantung koroner memiliki jenis pekerjaan yang tergolong berat mengakibatkan terjadinya keluhan sesak nafas saat bekerja sehingga sebagian besar responden penelitian memiliki jenis pekerjaan yang tergolong ringan untuk meminimalisir keluhan yang berkaitan dengan kelelahan saat bekerja maupun gangguan pernafasan.

\section{B. BIVARIAT}

\section{Hubungan Asupan Natrium dengan Tekanan Darah}

Asupan natrium merupakan salah satu asupan zat gizi yang dapat mempengaruhi tekanan darah dan angka kejadian hipertensi. Asupan natrium yang berlebih akan mempengaruhi perubahan tekanan darah. Asupan natrium anjuran PERKI (2015) bagi penderita penyakit jantung koroner asupan natrium tidak lebih dari $2000 \mathrm{mg}$.

Berdasarkan hasil penelitian, diketahui bahwa responden yang memiliki kategori asupan natrium tidak baik sebanyak $66 \%$ mempunyai tekanan darah tinggi dan responden yang memiliki kategori asupan natrium baik sebanyak $34,8 \%$ mempunyai tekanan darah tinggi. Hasil uji statistik menujukkan bahwa bahwa ada hubungan yang signifikan ( $p$-value $=0,004)$ antara asupan natrium dengan tekanan darah pasien penyakit jantung koroner rawat jalan.

Hasil penelitian ini juga sesuai dengan penelitian lain yang menyatakan adanya hubungan yang bermakna antara asupan natrium dengan kejadian hipertensi (Sarasaty, 2011). Selain itu, menurut penelitian (Aliffian, 2013) menyatakan ada hubungan yang bermakna antara asupan natrium dengan tekanan darah sistolik maupun diastolik penderita hipertensi.

Asupan natrium yang dikonsumsi oleh responden berasal dari bahan makanan baik yang mengandung natrium tinggi maupun bahan makanan rendah natrium. Makanan sumber natrium yang paling banyak dikonsumsi oleh responden seperti makanan sumber karbohidrat yaitu roti dan biskuit, makanan sumber protein seperti ikan asin maupun ikan yang dikalengkan, minuman seperti teh dan kopi, serta bumbu masakan seperti kecap maupun terasi. Konsumsi makanan sumber natrium juga sejalan dengan penelitian Widyaningrum (2012) yang menyatakan bahwa responden penelitian mengonsumsi makanan sumber natrium seperti biskuit, keripik, serta ikan asin. Konsumsi makanan sumber natrium ini terjadi karena bahan makanan tersebut terdapat dalam menu seharihari tanpa disadari oleh responden bahwa bahan makanan tersebut tergolong bahan makanan tinggi natrium.

Mekanisme terjadinya hipertensi akibat kadar natrium yang berlebih, yaitu pengaturan keseimbangan natrium dalam darah diatur oleh ginjal. Kandungan natrium yang tinggi dalam tubuh dapat mengganggu kerja ginjal. Natrium harus dikeluarkan dari tubuh oleh ginjal, tetapi karena natrium sifatnya mengikat banyak air, maka makin tinggi natrium membuat volume darah meningkat. Volume darah semakin tinggi sedangkan lebar pembuluh darah tetap, maka alirannya jadi deras, yang artinya tekanan darah menjadi semakin meningkat (Anggraini, dkk 2009). Sehingga, asupan natrium yang tinggi akan meningkatkan resiko terjadinya hipertensi.

Oleh karena itu, pasien penderita penyakit jantung koroner yang memiliki tekanan darah tinggi diharapkan mampu membatasi makanan tinggi natrium yang dikomsumsi sehari-hari seperti mengurangi jumlah garam yang digunakan dalam mengolah makanan serta bahan makanan lainnya seperti roti, kue, makanan yang dikalengkan maupun yang diawetkan, serta bumbu dapur seperti terasi dan kecap.

\section{Hubungan Aktifitas Fisik dengan Tekanan Darah}

Aktivitas fisik adalah setiap gerakan tubuh yang meningkatkan pengeluaran tenaga dan energi atau pembakaran kalori (Kemenkes RI, 2015). Aktivitas fisik dilakukan dengan cara menggerakkan tubuh oleh otot-otot rangka yang dihasilkan sebagai suatu pengeluaran tenaga yang meliputi pekerjaan, waktu senggang, dan aktivitas sehari-hari. Aktivitas fisik dalam penelitian ini dikategorikan berdasarkan jenis pekerjaan yang dilakukan responden baik ringan, sedang, maupun berat.

Berdasarkan hasil penelitian, diketahui bahwa bahwa responden yang memiliki kategori aktivitas fisik berat sebanyak $57,1 \%$ mempunyai tekanan darah tinggi dan responden yang 
memiliki kategori aktivitas fisik ringan sebanyak 50,6\% mempunyai tekanan darah tinggi. Hasil uji statistik menunjukkan bahwa tidak ada hubungan yang signifikan $(p$-value $=1,000)$ antara kategori aktifitas fisik dengan tekanan darah.

Penelitian Mubin, dkk (2010) bahwa hipertensi lebih banyak terjadi pada pekerja sebagai buruh/ petani karena salah satu faktor resikonya adalah berkaitan erat dengan cara hidup seseorang seperti cara dalam menghadapi permasalahan dan dipengaruhi juga oleh berat ringannya pekerjaan seseorang tersebut sehingga kejadian hipertensi paling banyak terjadi pada golongan pekerja seperti mereka. Selain itu, jenis pekerjaan baik kategori ringan, sedang, maupun berat memiliki tingkat stres kerja yang berbedabeda sehingga responden yang memiliki jenis pekerjaan yang termasuk ringan akan lebih memiliki tingkat stres kerja yang rendah pula dan begitu juga sebaliknya.

Selain itu, penelitian Nengsih (2015) menunjukkan bahwa ada hubungan yang bermakna antara stres kerja dengan kejadian hipertensi. Jenis pekerjaan yang memiliki tugas dan tanggung jawab yang besar memungkinkan terjadinya stres kerja atau ketegangan otak dalam bekerja sehingga mempengaruhi perubahan tekanan darah semakin meningkat.

Namun, sebagian besar responden penelitian ini memiliki aktivitas fisik ringan $(92,7 \%)$ karena jenis pekerjaan yang dimiliki oleh responden paling banyak ialah tidak bekerja. Responden yang tidak memiliki pekerjaan yang dimaksud ialah responden yang memiliki kategori aktivitas fisik ringan dalam kegiatan keseharianmya seperti menonton televisi, berbaring, dan tidur bukan berdasarkan ada atau tidaknya penghasilan atau pendapatan yang dimiliki.Jenis pekerjaan yang dimiliki seseorang dapat memicu terjadinya stres pada seseorang baik jenis pekerjaan yang berat seperti buruh atau petani hingga seseorang yang tidak memiliki pekerjaan.

Peningkatan tekanan darah lebih besar pada individu yang mempunyai kecenderungan stress emosional yang tinggi. Stress atau ketegangan jiwa dapat merangsang kelenjar anak ginjal melepaskan hormon adrenalin dan memacu jantung berdenyut lebih cepat serta lebih kuat, sehingga tekanan darah meningkat. Jika stress berlangsung lebih lama, tubuh akan berusaha mengadakan penyesuaian sehingga timbul kelainan organis atau perubahan patologis.

Oleh karena itu, pengaturan pola hidup sehat seperti melakukan aktivitas fisik yang teratur maupun melakukan olahraga ringan seperti lari pagi dapat dilakukan guna menghindari timbulnya stres yang akan mengkibatkan kenaikan tekanan darah.

\section{Hubungan Kebiasaan Merokok dengan Tekanan Darah}

Kebiasaan merokok telah ada sejak dahulu dan terus berkembang dan berlanjut sampai saat ini seiring dengan perkembangan industri yang semakin modern. Merokok adalah membakar tembakau yang kemudian dihisap asapnya, baik menggunakan rokok batangan maupun menggunakan pipa (Iqbal, 2008). Asap rokok yang dihisap mengandung berbagai jenis zat kimia yang berbahaya bagi kesehatan.

Berdasarkan hasil penelitian, diketahui bahwa bahwa responden yang memiliki kebiasaan merokok sebanyak $50 \%$ mempunyai tekanan darah tinggi dan responden yang tidak memiliki kebiasaan merokok sebanyak $51,1 \%$ mempunyai tekanan darah tinggi. Hasil uji statistik menunjukkan bahwa tidak ada hubungan yang signifikan ( $p$-value $=1,000)$ antara kebiasaan merokok dengan tekanan darah.

Kebiasaan merokok responden dalam penelitian ini dilihat dari apakah responden masih merokok atau tidak saat penelitian dilakukan. Berdasarkan hasil penelitian ini, dari 88 orang yang tidak memiliki kebiasaan merokok ternyata sebanyak 46 orang $(47,9 \%)$ mempunyai riwayat merokok sebelumnya. Responden yang memiliki riwayat merokok sebelum penelitian tidak dilakukan penilaian.Riwayat merokok responden ini, berhubungan dengan lamanya waktu yang dihabiskan untuk merokok sebelum responden benar-benar berhenti merokok.

Menurut hasil penelitian Setyananda (2015) ada hubungan yang bermakna antara lama merokok dengan tekanan darah seseorang, artinya semakin lama memiliki kebiasaan merokok, maka semakin tinggi kemungkinan menderita hipertensi. Dampak merokok akan terasa setelah 10-20 tahun pasca penggunaan rokok. Sehingga, riwayat lama merokok pada responden penyakit jantung koroner mempengaruhi tekanan darah pasien meskipun kebiasaan merokok responden sudah berhenti saat penelitian dilakukan.

Kerusakan pembuluh darah yang menyebabkan tekanan darah tinggi dipengaruhi oleh zat kimia yang terhisap dari asap rokok. Zat kimia beracun seperti nikotin dan karbon monoksida yang dihisap melalui rokok yang masuk ke dalam aliran darah dapat merusak lapisan endotel pembuluh darah arteri sehingga mengakibatkan proses artereosklerosis dan tekanan darah tinggi (Depkes RI, 2006). Nikotin pada prinsipnya akan mengakibatkan pembuluh 
darah menyempit dengan cepat sehingga organorgan tubuh akan kekurangan oksigen antara lain otak dan otot jantung. Pada pemakaian rokok jangka lama, nikotin juga akan mengakibatkan dinding pembuluh darah menjadi kaku dan berkapur (atherosklerosis) sehingga suplai oksigen ke organ-organ tubuh akan menurun sedikit demi sedikit. Semakin lanjut umur perokok dan semakin lama merokok makan semakin parah kondisinya terutama otak dan otot jantung.

Nikotin juga dapat membuat darah menjadi lebih mudah menggumpal. Gumpalan darah ini dapat menyumbat pembuluh darah otak dan otot jantung dan mengakibatkan matinya sel-sel otot jantung. Bila terjadi pada pembuluh darah otak akan mengakibatkan matinya sel-sel jaringan otak. Setiap kematian jaringan otot jantung maupun otak tidak akan dapat pulih kembali karena sel-sel otot jantung atau sel otak tidak dapat melakukan regenerasi (Octaviani, 2009). Oleh karena itu, pembuluh darah pada seseorang yang memiliki riwayat merokok tidak akan kembali pada keadaan semula meskipun kebiasaan merokok sudah berhenti.

\section{Hubungan Faktor Genetik Hipertensi dengan Tekanan Darah}

Faktor genetik adalah faktor penilaian berdasarkan hubungan dengan asal-usul dan perkembangan suatu organisme atau makhluk hidup atau kaitannya dengan sifat turuntemurun.Riwayat keluarga merupakan uraian atau diagram usia dan kesehatan, atau usia dan penyebab kematian dari setiap hubungan keluarga yang paling dekat, meliputi kakeknenek, orang tua, saudara kandung, anak, dan cucu.

Berdasarkan hasil penelitian, diketahui bahwa bahwa responden yang memiliki faktor gentik hipertensi sebanyak $67,3 \%$ mempunyai tekanan darah tinggi dan responden yang tidak memiliki faktor genetik hipertensi sebanyak 29,2\% mempunyai tekanan darah tinggi. Hasil uji statistik menunjukkan bahwa ada hubungan yang signifikan $(p$-value $=0,001)$ antara faktor genetik hipertensi dengan tekanan darah.

Sebagian besar responden memiliki garis keturunan dari orang tua baik ayah maupun ibu yang juga memiliki tekanan darah tinggi (hipertensi), hasil ini tidak berbeda dengan teori dan penelitian terkait.Berdasarkan penelitian Anggraini dkk tahun 2009 menyatakan ada hubungan yang bermakna antara seseorang dengan tekanan darah tinggi yang memiliki garis keturunan dalam keluarga yang juga memiliki hipertensi. Keluarga dengan riwayat hipertensi dan penyakit jantung koroner meningkatkan risiko terjadinya hipertensi dua sampai lima kali lipat (Almatsier dkk, 2013). Apabila riwayat hipertensi didapatkan pada kedua orang tua maka dugaan hipertensi penyebabnya belum diketahui secara pasti (hipertensi esensial) lebih besar.

Faktor genetik juga dipengaruhi faktorfaktor lingkungan lain, yang kemudian menyebabkan seorang menderita hipertensi. Menurut Sutanto (2010), jika seseorang termasuk orang yang mempunyai sifat genetik hipertensi primer (esensial) dan tidak melakukan penanganan atau pengobatan maka ada kemungkinan lingkungannya akan menyebabkan hipertensi berkembang dan akan mulai muncul tanda-tanda dan gejala hipertensi dengan berbagai komplikasinya. Oleh karena itu, seseorang yang memiliki faktor genetik hipertensi diharapkan mampu mengontrol tekanan darah melalui pemeriksaan secara rutin guna menghindari komplikasi hipertensi.

\section{SIMPULAN}

Hasil penelitian ini menunjukkan tidak ada hubungan antara aktifitas fisik dan kebiasaan merokok dengan tekanan darah pada penderita penyakit jantung koroner $(p$-value $=1,000)$. Untuk variabel asupan natrium dan faktor genetik terdapat hubungan yang bermakna yaitu dengan tekanan darah pada penderita jantung koroner ( $p$ value $<0,005$ ).

\section{SARAN}

Berdasarkan kesimpulan di atas, peneliti memberikan beberapa saran antara lain:

Bagi Rumah Sakit diharapkan meningkatkan kerjasama antara dokter dan ahli gizi untuk meningkatkan pengetahuan tentang makanan tinggi natrium melalui penyuluhan maupun konseling gizi untuk pasien jantung koroner dalam pengaturan makan serta merujuk pasien jantung koroner ke Poliklinik Gizi. Selain itu diperlukan peran ahli gizi untuk lebih aktif dalam memberikan pelayanan pada saat konsultasi gizi sehingga pasien berminat untuk datang ke ahli gizi. 


\section{DAFTAR PUSTAKA}

Aliffian, Imantino. 2013. Hubungan Asupan Natrium, Kalium, dan Magnesium Terhadap Tekanan Darah pada Penderita Hipertensi Rawat Jalan di Rumah Sakit PKU Muhammadiyah Surakarta. Naskah Publikasi. Surakarta: Fakultas Ilmu Kesehatan Universitas Muhammadiyah Surakarta.

Almatsier, Sunita. 2013. Prinsip Dasar Ilmu Gizi. Jakarta: PT. Gramedia Pustaka Utama.

Anggraini, dkk. 2009. Faktor-Faktor yang Berhubungan dengan Kejadian Hipertensi pada Pasien yang Berobat di Poliklinik Dewasa Puskesmas Bangkinang Periode Januari sampai Juni 2008. Pekanbaru: Universitas Riau.

Anwar, T. Bahri. 2004. Faktor Risiko Penyakit Jantung Koroner. Skripsi. Medan: Fakultas Kedokteran Universitas Sumatera Utara.

Departemen Kesehatan RI. 2006. Pedoman Teknis Penemuan dan Tatalaksana Penyakit Hipertensi. Jakarta: Direktorat Pengendalian Penyakit Tidak Menular.

Iqbal, Muhamad Fariz. 2008, Perilaku Merokok Remaja di Lingkungan RW.22 Kelurahan Sukatani Kecaman Cimanggis Depok Tahun 2008.Skripsi. Depok: Universitas Indonesia.

Kementerian Kesehatan RI. 2015. Pembinaan Kesehatan Olahraga di Indonesia. Jakarta: Pusat Data dan Informasi Kementerian Kesehatan RI.

Khasanah, Nur. 2012. Waspadai Beragam Penyakit Degeneratif Akibat Pola Makan. Yogyakarta: Laksana.

Kusumastuti, D. I. 2014. Hubungan Pengetahuan dengan Kepatuhan Diet Hipertensi pada Lansia Yang Mengalami Hipertensi di Panti Wredha Dharma Bakti Kasih Surakarta. Surakarta: STIKES Kusuma Husada.

Manganti, Alisa. 2012. Panduan Hidp Sehat Bebas Diabetes. Yogyakarta: Araska.

Mann, Jim dan Alexandra Chrisholm. 2014. Buku Ajar Ilmu Gizi. Jakarta: Buku Kedokteran EGC.

Meylisa. 2015. Karakteristik Penderita Hipertensi pada Poliklinik Rawat Jalan di RS. Universitas Hasanuddin, Makassar Periode Kunjungan Januari-Juni 2015. Skripsi. Makassar: Universitas Hasanuddin.

Mubin, MF, dkk. 2010. Karakteristik dan Pengetahuan Pasien dengan Motivasi Melakukan Kontrol Tekanan Darah di Wilayah Kerja Puskesmas Sragi I
Pekalongan. Semarang: Universitas Muhammadiyah Semarang.

Nengsih, Sri Kartini. 2015. Hubungan Stres Kerja dengan Hipertensi pada Karyawan Bagian Direktorat Operasi dan Komersial Pusat di PT. Pelindo IV Makassar Tahun 2015. Skripsi. Makassar: Universitas Hasanuddin.

Noviyanti. 2015. Hipertensi Kenali, Cegah, dan Obati. Yogyakarta: Notebook.

Octaviani, Rowella. 2009. Gambaran Pengetahuan, Sikap, dan Perilaku Merokok pada Staf Administrasi Pria di Universitas Indonesia Tahun 2009. Skripsi. Depok: Universitas Indonesia.

Perhimpunan Dokter Spesialis Kardiovaskuler Indonesia (PERKI). 2015. Pedoman Tatalaksana Hipertensi pada Penyakit Kardiovaskular. Jakarta: Indonesian Heart Association.

Rahayu, Endang. 2014. Kamus Kesehatan. Jakarta: Mahkota Kita.

Riskesdas. 2013. Laporan Hasil Riset Kesehatan Dasar (Riskesdas). Jakarta: Kementerian Kesehatan RI.

Roslina. 2008. Analisis Determinan Hipertensi Esensial di Wilayah Kerja Tiga Puskesmas Kabupaten Deli Serdang Tahun 2007. Tesis. Medan: Universitas Sumatera Utara.

Sarasaty, Rinawang Frilyan. 2011. Faktor-Faktor yang Berhubungan dengan Hipertensi pada Kelompok Lanjut Usia di Kelurahan Sawah Baru Kecamatan Ciputat, Kota Tangerang Selatan. Skripsi. Jakarta: Universitas Islam Negeri Syarif Hidayatullah.

Setyananda, dkk. 2015. Hubungan Merokok dengan Kejadian Hipertensi dada LakiLaki Usia 35-65 tahun di Kota Padang. Jurnal Kesehatan Andalas. Padang.

Sihombing, Marice. 2010. Hubungan Perilaku Merokok, Konsumsi Makanan/Minuman, dan Aktivitas Fisik dengan Penyakit Hipertensi pada Responden Obes Usia Dewasa di Indonesia. Pusat Penelitian dan Pengembangan Biomedis dan Farmasi, Badan Penelitian dan Pengembangan Kesehatan. Jakarta.

Sitorus, Ronald. 2010. Gejala Penyakit dan Pencegahannya. Bandung: Yrama Widya.

Sulviana, Nova. 2008. Analisis Hubungan Gaya Hidup dan Pola Makan Dengan Kadar Lipid Darah dan Tekanan Darah pada Penderita Jantung Koroner. Skripsi. 
Bandung: Fakultas Pertanian Institut Pertanian Bogor.

Sutanto. 2010. CEKAL (Cegah dan Tngkal) Penyakit Modern (Hipertensi, Stroke, Jantung, Kolesterol, dan Diabetes). Yogyakarta: CV. Andi Offset.

Widyaningrum, Siti. 2012. Hubungan antara Konsumsi Makanan dengan Kejadian Hipertensi pada Lansia. Skripsi. Jember: Universitas Jember.

World Health Organization. 2013. World Health Statistics in 2013. http://www.who.int/gho/publications/world _health_statistics/EN_WHS2013_Full.pdf

World Heart Federation. 2012. Deaths Due to Cardiovascular Disease.

http://www.world-heart-

federation.org/cardiovascularhealth/global-facts-map.

Yulsam, Putri Yuriandini, Fadil Oenzil, Efrida. 2015. Insidens Riwayat Hipertensi dan Diabetes Melitus pada Pasien Penyakit Jantung Koroner di RS. Dr. M. Djamil Padang. Jurnal Kesehatan Andalas. Padang. 